\title{
Terrorism from Above and Below in the Age of Globalization"
}

\author{
Asafa Jalata \\ University of Tennessee, Knoxville, USA \\ Email: ajalata@utk.edu \\ Received December 20 $0^{\text {th }}, 2010$; revised January $10^{\text {th }}, 2011$; accepted January $24^{\text {th }}, 2011$.
}

\begin{abstract}
This paper explains how the intensification of globalization as the modern world system has increased the occurrence of terrorism from above (i.e. state actors) and from below (i.e. non-state actors). We cannot adequately grasp the essence and characteristics of modern terrorism without understanding the larger cultural, social, economic, and political contexts in which it takes place. Since terrorism has been conceptualized, defined, and theorized by those who have contradictory interests and objectives and since the subject matter of terrorism is complex, difficult, and elusive, there is a wide gap in establishing a common understanding among the scholars of terrorism studies. Most experts on the subject look at this issue from a narrow perspective by ignoring the reality that terrorism is a "social cancer" for all human groups affected by it. First, this paper defines the concept of terrorism in relation to different forms of terrorism, and explains how it has increased with the intensification of globalization. Second, taking the events of $9 / 11$ and the case of Ethiopian state terrorism, the piece explores the general impacts of all forms of terrorism.
\end{abstract}

Keywords: Terrorism, Globalization, 9/11, Capitalism, Terrorism Studies, Genocide, Colonial Terrorism

\section{Introduction}

This paper explains how the intensification of globalization as the modern world system with its ideological intensity of racism and religious extremism has increased the danger of all forms of terrorism. In this world system, the contestation over economic resources and power, the resistance to domination and repression, and religious and ideological extremism have increased the occurrence of terrorism from above (i.e. state actors) and from below (i.e. non-state actors). However, terrorism as a "technique is as old as warfare contrary to the widespread notion that [it] was the offspring of nineteenth-century nationalist movements. The confusion may be a result of the late [emergence] of the term in the French Revolution and its Terror" (Chaliand and Blin, 2007: 5-6). Although there have been human groups that have engaged in peaceful co-existence and cooperation and have shared their available resources, history demonstrates that since time immemorial, individuals, groups or organizations have engaged in conflict, war, terrorism, and genocide over economic interests such as land, water, and commerce (Wilkinson, 1979: 45-72; Black, 2004: 21-22).

But the intensity and danger of terrorism and genocide have increased with the advancement of technology - first with gun making and subsequently with the production of other powerful weapons. Furthermore, currently rapid technological revolutions and advancements have more globalized the threat of terrorism from a distance and have multiplied its destructive capacity. According to Donald Black (2004: 21-22), "Rapid transportation and electronic communication shrink the world by shortening the time needed to travel and interact across the physical world ... As physical distance loses its relevance, terrorists can more easily plan and launch attacks thousands of miles from home, illustrated by the American attacks of Sep-

*Paper presented at the Oak Ridge Institute for Continued Learning Philosophical Society, November 7, 2008. tember 11, 2001 - literally impossible less than a century earlier."

Unfortunately, at this historical moment our understanding about the origins and causes of human violence and terrorism is very limited (Wilkinson, 1986: 45). The main intention of this paper is to present a critique of terrorism studies, identifying the shortcomings of this area of study, and to increase our comprehension of all forms of terrorism and its devastating consequences in different parts of the modern world. First, the paper deals with some historical and theoretical issues in order to lay down the foundation of my discussion. Second, it identifies two forms of terrorism, explaining how it has increased with the intensification of globalization, and provides a pragmatic and practical definition of the subject matter. Third, taking the events of 9/11 and the case of Ethiopian state terrorism, the paper explores the general impacts of terrorism from both below and above.

\section{Historical and Theoretical Issues in Terrorism Studies}

Since the frequency, intensity, and the volume of terrorism have increased alongside the development of global capitalism, (Hochschild, 1999; Kiernan, 2007; Thoronton, 1987), we cannot adequately understand the full essence and characteristics of terrorism without considering the existence of links between increased incidences of terrorism and the racialized capitalist world system (Jalata, 2001). As capitalism developed in Western Europe in the late $15^{\text {th }}$ century and expanded to the rest of the world through colonialism, state-sponsored terrorism and genocide also spread as integral parts of the capitalist world system. Beginning in 1492, European colonialists engaged in terrorism, genocide, and enforced servitude in the Americas and later extended their practices into Africa through racial slavery and colonialism (De Las Casas, 1992; Kiernan, 2007; 
Thoronton, 1987). Then, in the $19^{\text {th }}$, the colonialists fully incorporated other parts of the world such as Africa and Asia into this system through colonial terrorism and genocidal wars (De Las Casas, 1992; Hochschild, 1999).

Bartolomé De Las Casas (1992: 15), a priest who traveled to the New World in 1502 with the Spaniards in their quest to colonize and rob the treasures and lands of the indigenous peoples of the Indies, provides an eyewitness account of the anatomy of colonial terrorism and genocide:

They forced their way into native settlements, slaughtering everyone they found there, including small children, old men, pregnant women, and even women who had just given birth. They hacked them to pieces, slicing open their bellies with their swords as though they were so many sheep herded into a pen. They even laid wagers on whether they could manage to slice a man in two at a stroke, or cut an individual's head from his body, or disembowel him with a single blow of their axes. They grabbed suckling infants by the feet and, ripping them from their mothers' breasts, dashed them headlong against the rocks. They spared no one, erecting especially wide gibbets on which they could string their victims up with their feet just off the ground and then burn them alive thirteen at a time, in honor of our Savior and the twelve Apostles, or tie dry straw to their bodies and set fire to it. Some they chose to keep alive and simply cut their wrists, leaving their hands dangling, saying to them: 'Take this letter'-meaning that their sorry condition would act as a warning to those hiding in the hills.

The criminal acts that De Las Casas describes above were guided and financed by the government of Spain (Cohen, 1986: 32-36). De Las Casas explained that the crimes committed against humanity in the Indies for gold, silver, food, land and other resources were committed in the name of Christianity and/or European civilization. Most mainstream and leftist scholars have conveniently ignored the terrorism and genocide committed against such indigenous groups during the expansion of the European-dominated racialized capitalist world system. According to Martin Shaw (2003: 65), a "larger concentration of state power grew with the expansion of European empires in the 'Orient' and the 'New World,' accompanied by waves of slaughter of people who were often seen, in the religious ideology of the time, as less human than Christian Europeans. In the Americas, the most 'advanced' European societies waged genocidal war, wiped out whole civilizations and instituted the most extensive slave system."

When "state terrorism can be seen as a method of rule whereby some groups of people are victimized with great brutality, and more or less arbitrarily by the state or state supported actors, so that others who have reason to identify with those murdered, will despair, obey or comply" (Schmid, 1991: 31), genocide can be defined as the elimination in part or in whole a certain group of people in order to expropriate their resources or to stop their resistance to the state or the agents of the state. In the example above, the colonial Spaniards committed terrorism and genocide in order to transfer the territories and resources of the indigenous peoples to themselves and their descendants. Similarly, several European governments had engaged in such crimes (Kiernan, 2007). While the colonizing nations of the West and their collaborators had justified "their scramble for foreign territories as fulfillment of a sacred duty to spread their form of civilization to the world" (Bodley, 1990: 12), the genocide and ethnocide committed by such nation-states was called by John H. Bodley "an immense human tragedy" (Bodley, 1992: 37). According to this scholar, between 1820 and 1920, Western Europeans and their descendants terrorized and massacred about 50 million people (Bodley, 1990).

The more human beings became advanced in technology and organizational capacity, the more they engaged in terrorism and genocide in order to satisfy their group's or country's economic interests. Western European countries such as Spain, Portugal, England, France, Holland, Germany, and Belgium increasingly committed crimes against humanity during their capitalist colonial expansion to the Americas, Africa, Asia, and Australia, and used the discourses of the superiority of their race, culture, civilization, and Christian religion to promote and justify their destructive and exploitative policies. The experiences of indigenous peoples from various continents illustrate that most of them that survived colonial terrorism and genocide were reduced to the status of slavery or semi-slavery and were forced to serve the colonizers and their descendants.

Unfortunately, most social scientists of the $19^{\text {th }}$ century justified "a deliberate and violent political act carried out as national policy in order to gain access to the natural resources controlled by" indigenous peoples, and 'espoused 'scientific' evolutionary theories that explained the destruction and suggested that it was inevitable" (Bodley, 1992: 38). The West and their collaborators also used the ideologies of racism (Jalata, 2001: 8) and religious absolutism to justify colonial terrorism, war, slavery, and genocide. Despite the fact that "ideologies [as] qua abstract doctrine do not in themselves directly cause violence, ideological movements, which define enemies and incite to combat, do frequently instigate political violence, wars, and "crusades" (Wilkinson, 1979: 62).

Under the guise of "scientific" theories, some scholars have justified the destruction of indigenous peoples (Wilkinson, 1979; Bodley, 1990). "Scientific" claims have been made to promote personal and group interests at the cost of humanity. Generally speaking, my critique of mainstream literature on terrorism is intended to suggest that most scholars from both the right and the left have yet to establish a single practical, moral, legal, and scholarly standard to promote and protect human rights that would enable them to go beyond the discourses of commerce or money, culture, religion, and civilization in order to critically understand the root causes of terrorism from above and below and to develop appropriate policy suggestions. By focusing on non-state terrorism (Netanyahu, 1995) or state terrorism, scholars of global and terrorism studies have avoided providing comprehensive and critical analyses and an objective definition and theorization of this subject. By dealing with all forms of terrorism as aspects of the capitalist world system, this paper seeks to close this gap in scholarship.

Even critical scholars such as Karl Marx, Andre Gunder Frank, Immanuel Wallerstein, and others who have studied the emergence, development, and expansion of the racialized capitalist world system have primarily focused on trade, the international division of labor, exploitation, capital accumulation, political structures, development and underdevelopment, and 
social inequality and thus have ignored the role of terrorism in creating and maintaining the system. According to Karl Marx (1967: 753-754), "The colonies secured a market for the budding, manufactures and, through the monopoly of the market, an increasing accumulation. ... As a matter of fact, the methods of primitive accumulation are anything but idyllic. In actual history it is notorious that conquest, enslavement, robbery, murder, briefly force, plays the great part. In fact, the veiled slavery of the wage workers in Europe needed, for its pedestal, slavery pure and simple in the new world. Capital comes [into the world] dripping from head to foot, from every pore, with blood and dirt." Similarly, Andre Gunder Frank (1979) wrote about the global accumulation of capital between 1492 and 1789. Immanuel Wallerstein also published several books and articles to explain how capitalism became the global system. Despite this, he too has not adequately explained the role of terrorism in creating and maintaining the capitalist world system.

Such critical scholars have not adequately addressed the role of state-centered or state-sponsored terrorism in destroying or enslaving the indigenous peoples of the world and in creating, developing, and maintaining the racialized capitalist world system. Despite the fact that Marx did recognize the cruelty and consequences of the capitalist world system, he did not explore the idea that terrorism was an integral part of the broadening of the system. Marx focused on capitalist development in Europe and indirectly studied its relations to colonized societies. Other critical scholars have also followed his Euro-centric paradigm.

We learn from history that political violence has increased as different societies with improved techniques of production have produced surplus wealth, developed their organizational capacity, and attained further technological innovations. In the $16^{\text {th }}$ century, with such economic and technological advancements countries such as England, France, Italy, Spain, Portugal, and the Netherlands formed the nation-states (Frank, 1978: 51-52). The emergence of the nation-state with the development of capitalism in Europe created the organizational and technological capacity to engage in more lethal violence and war. In the $16^{\text {th }}$ century, capitalism had "witnessed the first long, sustained, and widespread quantitative and qualitative development ... in its mercantile stage and the first period of concentrated capital accumulation in Europe" (Frank, 1978: 52). As competition increased among individuals, groups, and states over scarce and valued resources, political violence, terrorism, and war increased.

As capitalism developed in Western Europe, the need for raw materials, minerals such as gold and silver, markets, and free or cheap labor expanded due to the desire to minimize the cost of production and to increase the accumulation of capital or wealth. "The treasures captured outside of Europe by undisguised looting, enslavement, and murder," Karl Marx (1967: 753-754) writes, "floated back to the mother-country and were there turned to capital." Most liberal and leftist scholars have failed to identify and explain the role of state-sponsored or state terrorism that colonial officials, European companies, and expeditionary forces used during the expansion of the racialized capitalist world system to transfer the economic resources of the indigenous peoples to European colonial forces or settlers and their collaborators. The development of the nation-state and the capitalist world system occurred through war making, violence and organized crime (Tilly, 1985: 170). We cannot clearly understand the essence and meaning of global terrorism without comprehending the essence and characteristics of state terrorism since states were born and consolidated through violence.

Under the guises of "free markets," "civilization," and Christianity, forces of European states or state-sponsored companies committed acts of terrorism and genocide that were, more or less, ignored. In fact, the issue of terrorism only started to be addressed when, after World War I, colonized peoples in Africa and Asia began their liberation struggles against European colonial states. The terrorist attack on the life and liberty of American indigenous peoples by European colonial powers and their collaborators destroyed existing institutions and economies and exposed the conquered peoples to poverty and famine-induced "holocausts" (Davis, 2001). Discussing how the cultural destruction of indigenous peoples resulted in massive deaths, Karl Polanyi (1944: 159-160) argues, "The catastrophe of the native community is a direct result of the rapid and violent disruption of the basic institutions of the victim. These institutions are disrupted by the very fact that a market economy is foisted upon an entirely differently organized community; labor and land are made into a commodity, which, again, is only a short formula for the liquidation of every ... cultural institution in an organic society."

The capitalist world economy that in the $19^{\text {th }}$ century was permanently eliminating famine from Western Europe was simultaneously accelerating famine and famine-induced deaths in the rest of the world: "Millions died, not outside the "modern world system,' but in the very process of being forcibly incorporated into its economic and political structures. They died in the golden age of Liberal Capitalism; indeed, many were murdered by the theological application of the sacred principles of [Adam] Smith" (Davis, 2001: 9). Today, mainstream Euro-American scholars gloss over such crimes and refer to them as actions of "discovery" and "civilization." State terrorism, genocide, and the destruction of indigenous institutions and the devastating consequences of famine have been closely interconnected in the global capitalist world system. In addition, the international community rarely holds accountable its members that engage in state terrorism and genocide. Kurt Jonassohn (1998: 24) recently noted that terrorist state leaders in developing countries "not only go unpunished, they are even rewarded. On the international scene they are accorded all the respect and courtesies due to government officials. They are treated in accordance with diplomatic protocol in negotiations and are treated in the General Assembly of the United Nations. When they are finally ousted from their offices, they are offered asylum by countries that lack respect for international law, but have a great deal of respect for the ill-gotten wealth that such perpetrators bring with them."

Despite the fact that some government elites claim that the state provides protection from domestic and external violence, "governments organize and, wherever possible, monopolize the concentrated means of violence. The distinction between 'legitimate' and 'illegitimate' force makes no difference" (Tilly, 1985: 171). Political violence has always been involved in producing and maintaining structures, institutions, and organizations of privileged hierarchy and domination in society. Those who have state power, which incorporates the power to 
define terrorism, deny their involvement in political violence or terrorism and confuse abstract theories about the state with reality. Based on an idealized relationship between the state and society, philosophers and thinkers such as Hobbes, Hegel, Rousseau, and Plato have identified three functions of the state that would earn it legitimacy. According to state theories, the state protects and maintains internal peace and order in society; it organizes and protects national economic activities; it defends national sovereignty and national interests (Bushnell, et al., 1991: 6). In reality, most states violate most of these theoretical principles by engaging in political repression and state terrorism in order to defend the interests of a few powerful elites. Furthermore, the revolutionary theories of the state by Karl Marx and V. I. Lenin (1971) remain a dream because states failed to introduce revolutionary social transformations that would eliminate oppression, repression, state terrorism, and the exploitation of people (Maguire, 1978).

The occurrence of political repression, oppression, state terrorism, and dictatorship in the former Soviet Union, China and other former revolutionary countries demonstrate that the state has remained the site of violence despite its legitimating discourse. As Charles Tilly (985: 18-19) puts it, political violence is closely related to the art of statecraft, and most of the time, "the state, like an unchained beast, ferociously [attacks] those who claim to be its master, its own citizens" (Tilly, 1985: 7). Annamarie Oliverio (1998) criticizes scholars who produce definitions of terrorism on behalf of the state and promote outmoded concepts, analyses, and theories in state bureaucracy, the media, and in academia.

The motivations of those who hold state power and engage in state terrorism are to maintain the global economy, structures of politics, and hierarchies of cultures and peoples in order to extract economic resources. The main objective of those who engage in non-state terrorism is mainly to politically respond to economic, political, and cultural inequalities. One common denominator of the theories of non-state terrorism is that it is mainly caused by grievances of one kind or another. These grievances involve national/religious/cultural oppression, economic exploitation, political repression, massive human rights violations, attacks on life and liberty, state terrorism, and various forms of social injustices. Yet, whilst it is acknowledged that revolutions, social movements, and non-state terrorism generally involve grievances, all grievances do not result in revolutionary or social movements, nor do they all cause subversive terrorism. There must therefore be some intervening structural, conjunctural, and behavioral factors particularly that act to transform some grievances into non-state terrorism through some agencies of the aggrieved population.

The combination of factors such as collective grievances, the continued oppressive and exploitative policies of state elites, the refusal of state actors to address longstanding grievances peacefully and fairly, the development of extreme ideologies in the form of religion or another ideology, and the emergence of leaders, ideologues, and cadres in aggrieved populations can facilitate the emergence of subversive terrorism. We cannot adequately grasp the essence and characteristics of modern terrorism without understanding the larger cultural, social, economic, and political contexts in which it takes place. Since terrorism has been conceptualized, defined, and theorized by those who have contradictory interests and objectives and since the subject matter of terrorism is complex and elusive, there currently is a wide gap in establishing a common understanding of terrorism among scholars of terrorism studies. Most experts on the subject look at this issue from a narrow perspective by ignoring what I argue to be the reality: that terrorism is a social cancer for all human groups affected by it.

\section{Conceptualizing, Defining, and Understanding Terrorism}

Terrorism is a contested concept due to the failure of scholars of terrorism studies in establishing a commonly accepted definition because of their self- and group-centeredness or limited perspectives. Despite the fact that the scholars of terrorism studies agree that terrorism primarily involves the unleashing of lethal violence primarily on civilians in order to influence an audience, they do not agree on who and what the agencies of all forms of terrorism are. Referring to the case of contemporary sub-state terrorism, for instance, Omar Lizardo (2008: 102) attempts to provide a definition: "Modern terrorism refers to a type of violent interaction initiated by a non-state actor, which is not formally recognized as a legitimate wielder of the means of violence or a valid initiator of violent interactions, directed against the representatives (human, material or symbolic) of a formally recognized state actor in the international system, which does not follow the institutionalized rules and conventions of military engagement" [author's emphasis].

Since Lizardo's definition focuses only on bottom-up terrorism, he is not addressing all forms of terrorism. For Martha Crenshaw (1981: 379), terrorism is "the premeditated use or threat of symbolic, low-level violence by conspiratorial organizations." For scholars such as Lizardo and Crenshaw, terrorism is defined as premeditated or intentional violence carried out by non-state actors in order to impose fear on a target population and to achieve certain political objectives. And according to Walter Enders and Todd Sandler (2006: 3), states do not perpetrate terrorism; only individuals or sub-national groups commit terrorism. Many other scholars define terrorism without identifying whether states or non-state actors commit it (Oots, 1986; Cooper, 2001: 881-893; Tilly, 1985: 169-191). Explaining the challenges of conceptualizing terrorism, Leonard Weinberg, Ami Pendahzur, and Sivan Hirsch-Hoefler (2004: 786) define terrorism as follows: "Terrorism is a politically motivated tactic involving the threat or use of force or violence in which the pursuit of publicity plays a significant role," [author's emphasis]. Overall, most scholars do not address how many states do engage in terrorist activities, but do not publicize their illegal activities due to the fear of repercussion from the international system. For instance, states that openly engage in terrorist activities and gross human rights violations could be indicted by the International Criminal Court.

Yet, there are scholars who acknowledge that state terrorism begets non-state terrorism: "When terrorism is theoretically examined as a form of social control, fundamental controlling apparatuses of the state may be viewed as terroristic. Organizations, groups, and individuals who legitimate the use of violence to achieve their goals may be viewed as products, extensions, or models of the essential structure of a state when its purpose is to regulate behavior via various forms of repression, 
domination, and terror" (Oliverio, 1998: 7). Furthermore, as Eqbal Ahmad (1998: 5) argues, "state terror very often breeds collective terror."

Although several representative definitions of terrorism converge on the notion that terrorism is "the deliberate use of violence in order to influence some audience (or audiences) [author's emphasis]," the definitions diverge on several issues such as which agencies engage in terrorism and who exactly the targets of terrorism are (Goodwin, 2006: 2028). Some ignore the issue of state terrorism altogether while others "seek to denounce a focus on state terrorism as 'skewed,' 'biased,' ideological and 'out of touch with real political events"' (Stohl and Lopez, 1984: 3). Those who study terrorism do not adequately explain why certain human elements, groups, organizations or states seek to impose control over other human beings through violence, nor do they include in their definitions the specific characteristics of the varied forms of terrorism.

Commentators and scholars such as Samih K. Farsoun and Naseer H. Aruri (2006), who are sympathetic towards liberation fronts such as the Palestinian Liberation Organization or other oppositional organizations, have not denounced their terrorist activities, preferring to endorse the idea that "one man's terrorist is another man's freedom fighter." Brian M. Jenkins (1981: 6-7) challenges this notion on the grounds that it "implies that there can be no objective definition of terrorism and that there are no universal standards of conduct in peace or war." On the other hand, scholars and politicians such as Benjamin Netanyahu (1995) have disregarded the alternate principle that "one man's terrorist is everyone's terrorist." Netanyahu never recognizes that the Israeli state engages in terrorism against Palestinians. Those who take these extreme positions ignore the crimes committed against humanity. I argue that any balanced definition of and theory about terrorism must consider all attacks by both state and non-state actors as attacks on the life and liberty of noncombatant civilians as terrorist. To illustrate my point, let me briefly introduce such terrorist episodes.

Before Nazi Germany committed large-scale genocide on Jews, it engaged in small-scale terrorist episodes in its preparation to attempt to annihilate an entire people. For example, on November 11, 1938, known as Kristelnacht or the "night of broken glass", the Nazis murdered ninety-one Jews. In this case, terrorism was the first phase of genocide, and the German state and its supporters committed it. In the two following cases, terrorism did not lead to genocide, and non-state actors committed it. One of these terrorist events deals with the attack by a Jewish terrorist group on Palestinian Arabs. On the night of December 18, 1947, armed Jewish men threw grenades on the homes of sleeping Palestinian families, killing ten people including women and children, and wounding five in the village Khisas in Palestine. This terrorist act was committed to frighten the surviving Palestinian families into leaving their homes so that the Jews could implement their Zionist plan of ethnic/racial “cleansing." As Jamal R. Nassar (2005: 46) describes,

The most frequently mentioned incident between the many contributing to a panic flight of the Palestinian inhabitants was the terrorist massacre of Deir Yassan. On April 9, 1948, Irgum attackers massacred 254 men, women, and children in the village of Deir Yassin. The Irgun was a militant Zionist group led by Menachem Begin, who became Israel' prime minster in 1977. Under British rule in Palestine, Begin was a wanted terrorist. His group, the Irgun, committed hundreds of acts of violence targeting both civilians and public sites. The Irgun also involved itself in assassinations and sabotage. Such incidents contributed to a massive exodus of the Palestinian Arab population and opened the door for the creation of the Jewish state.

Another terrorist episode involved a Palestinian group called Black September. At the 1972 Summer Olympics, this group broke into the dormitory rooms of an Israeli sport team in $\mathrm{Mu}-$ nich, Germany, and took eleven athletes and coaches hostage. Despite the fact that this event was being viewed on television by about 900 million people around the world, the terrorist group killed all the hostages. Whether states or non-state actors commit terrorist acts as such or whether Germans or Jews or Palestinians commit them, regardless of their claims, the violent attacks on noncombatants are terrorism of one form or another. Of course, in most cases, it is oppressive state policies and actions that facilitate the emergence of non-state terrorism. Hence, it is impossible to understand the essence and characteristics of all forms of terrorism and to challenge it without making state terrorists accountable for their crimes against humanity.

It is generally accepted among the experts of terrorism studies that there is a lack of consensus on a precise definition of terrorism (Hoffman, 2006[1998]: 28). Despite his recognition of the elusiveness of defining of terrorism, Bruce Hoffman (1998: 40) conceptualizes terrorism as "the deliberate creation and exploitation of fear through violence or the threat of violence in the pursuit of political change. Terrorism is specifically designed to have far-reaching psychological effects beyond the immediate victim(s) or object of the terrorist attack." He goes on to explain the roles of state and non-state terrorism and the difference between state and international terrorism. Hoffman argues that "one of the fundamental [reason] of international terrorism is a refusal to be bound by such rules of warfare and codes of conduct. International terrorism disdains any concept of delimited areas of combat or demarcated battlefields, much less respect of neutral territory." It is true that non-state terrorists care less about international rules of warfare and codes of conduct. Yet, what he does not address is that although states claim to abide by these rules and codes of conduct during wars, they also frequently violate them and frame their terrorist attacks on noncombatant populations as "collateral damage," as we shall see below. Furthermore, despite the fact that he associates the emergence of contemporary terrorism with the end of empires, he fails to discuss the essence and impact of colonial terrorism that the West and its collaborators imposed on indigenous peoples in the Americas, Australia, Africa, and Asia.

Alex P. Schmid and Albert J. Jongman (1988: 1) agree that the "search for an adequate definition is still on," even after examining more than one hundred pages of 108 definitions of terrorism in order to formulate a broadly acceptable and comprehensive definition. What is a key to recognize is that this comprehensive and clear definition cannot be established without a critical understanding of the role of the state in the capitalist world system. Theoretically speaking, the state "is often considered as an impartial arbiter between the groups and 
classes in society, wielding the legitimate monopoly of violence to maintain public order" (Schmid, 1991: 27). Practically, however, the state can be a terrorist agency. Schmid (1991: 3-4) clearly understands the role and impact of state terrorism when he writes:

State terrorism goes beyond the legitimate use of violence by those holding the reins of power, just as war crimes go beyond what is considered permissible in warfare. Many acts of terrorism such as hostage taking, killing of prisoners, and deliberate attacks on civilians are prohibited by the rules of war. If a state deals with political opponents by tactics which include selective and random murder, abduction and secret torture, massacres, and the use of concentration camps, it engages in methods which might be legalized by the state's own lawmaking machinery, but which are widely considered as contrary to humane and civilized behavior. These violent methods of control are also contrary to covenants of international law that most states have signed.

However, Schmid does not explain how dictatorial or colonial regimes also ignore international rules of warfare and codes of conduct and engage in organized terror. He also glosses over the fact that Western countries protect the rights of their respective citizens to some degree while violating the rights of the people of the Global South previously through colonial terrorism and currently by allying with and supporting post-colonial state terrorist regimes. Furthermore, this perceptive scholar does not explain why state or non-state agencies engage in terrorism. In South and Central America, Africa, and Asia, powerful Western countries have directly or indirectly supported the policies and practices of state terrorism while giving lip service to the principles of democracy and human rights. Focusing on state-sponsored terrorism that emerged in the peripheral world with the help of the West and naming it "the real terrorist network", Edward S. Herman (1982: 3) notes the following:

There is huge tacit conspiracy between the U.S. government, its agencies and its multinational corporations, on the one hand, and local business and military cliques in [the Global South], on the other, to assume complete control of these countries and 'develop' them on a joint venture basis. The U.S. security establishment to serve as the 'enforcers' of this joint venture partnership carefully nurtured the military leaders of the [peripheral] World, and they have been duly supplied with machine guns and the latest data on methods of interrogation of subversives.

With the support of powerful countries from the West and the East, terrorist regimes in peripheral nations have used various forms of terror such as rape, physical and psychological torture, violent arrest, secret or open imprisonment and usually death, disappearances, assassinations, and castration (Herman, 1982: 3). Claiming that they would promote "socialism" and social justice, the former Soviet Union, China, and other states have also been involved in assisting terrorist regimes in developing countries (Adelman, 1991: 99-112).

Large-scale state violence and terrorism have been practiced in societies where so-called socialist revolutions and national liberation movements have emerged. In order to win a war or to get publicity, these warriors sometimes engaged in terrorism by violently attacking civilian populations (Waltzer, 1977). The perpetrators call such casualties "collateral damage." Some scholars, commentators, and leaders fail to expose such terrorism and consider them to be legitimate acts of war. However, killing noncombatant people is both morally and legally wrong and must be exposed and criminalized. As Michael Waltzer argues, we should "regard life and liberty as something like absolute values and then try to understand the moral and political processes through which these values are challenged and defended" (Waltzer, 1977: xvi).

Since the international system, particularly the United Nations, lacks a single standard for humanity in practice (Jonassohn, 1998: 24), almost all states get away with the crimes they commit against their own citizens and other peoples. What some powerful countries did during the WWII demonstrate this reality as Virginia Held (2004: 68) notes: “ordinary warfare often uses terror as a tactic, and we should remember that the terror bombings of Dresden, Hiroshima, and Nagasaki undoubtedly killed far more people than have been killed by all terrorists, as conventionally so labeled throughout the world in all of the years since." Although the regimes of Germany, Japan, and Italy inflicted millions of deaths on various population groups during WWII which I argue were terrorist and genocidal acts, these criminal acts do not justify the bombing and the killing of innocent children and women in these countries.

Similarly, the recently U.S. war in Iraq resulted in the deaths of millions of noncombatant individuals and groups. The U.S. arguably has a legitimate right to attack Al Qaeda since the latter opened war on the American people. Although it is acceptable to attack the base of this terrorist organization in Afghanistan, I argue that it is morally and politically wrong to attack and kill noncombatant Afghans. Michael Waltzer and John Rawls put forward the principle of "supreme emergence" which suggests that soldiers and state-persons can override the rights of innocent, noncombatant people under the rule of necessity.

Justifying Great Britain's bombing of German cities and killing of women and children in the early 1940s, Waltzer (1977: 253) argues that Nazism's 'threat to human values [was] so radical that its imminence would surely constitute a supreme emergency; and this example can help us understand why lesser threats might not do so." I argue that this principle must be rejected since it ignores the victimization of noncombatants during wars. It is more agreeable that, as C. A. J. (Tony) Coady (2004: 93) writes:

The discussion of terrorism and supreme emergency does in any event clearly face us with two options. Either we insist that terrorism is always morally wrong and [should] never be allowed, or we accept that there can be circumstances in which the values served by terrorist acts are so important that it is right to do them. If [we exempt a terrorist act], then this exemption cannot be allowed only to states. Its legitimacy must in principle be more widely available, and decided on a case-by-case basis. My own conviction is that we surely [would] do better to condemn the resort to terrorism outright with no leeway for exemptions, be they for states, revolutionaries or religious and ideological zealots. 
Since the main sources of terrorism have been states (Perdue, 1989) states should not be exempted from being morally, legally and politically held responsible for engaging in any kind of terrorism. The same standard should be applied when criticizing and challenging non-state actors and their acts of terrorism.

Once we accept that policies and actions of states can beget bottom-up terrorism, we must, through international court, hold accountable, both morally and legally, all entities that engage in crimes against humanity in the name of religion, civilization, progress, revolution or ideology. This is the first step toward establishing a clear and acceptable boundary between legitimate and illegitimate political violence in the modern world system. Practically, the boundary is blurred, and people take various positions on the issues of terrorism. We need a broader and more critical understanding of the complexity and multiplicity of terrorism in order to establish a clear boundary between legitimate and illegitimate violence. There is no question this raises a serious challenge for defining and theorizing terrorism.

Despite scholars and commentators recognize the existence of different forms of terrorism, they have yet to define and study them in a balanced way. "Just as an increasing number of commentators seem to be able to even-handedly apply the term 'terrorist' to non-state and state actors," Grant Wardlaw (1989: 4) notes, "they will have to apply it even-handedly to those groups with whose cause they agree and those with whose cause they conflict." Having made this significant point, Wardlaw fails to explain why liberation fronts such as the Algerian FLN, the Vietnamese NLF and other liberation fronts in the Middle East, Africa, South America, and Europe are called terrorist organizations (Wardlaw, 1989: 24). The failure to understand or the refusal to recognize how state terrorism begets the non-state terrorism of liberation fronts and other organizations denies the opportunity to understand the challenge of terrorism. Commentators and scholars who fail to understand the complexity and multiplicity of terrorism characterize revolutionary leaders who challenge state terrorism as terrorists (Alexander, Browne and Nanes, 1979: 9-10). The failure to differentiate those who have legitimate grievances and are fighting against the injustice of the state from right wing terrorist leaders or organizations and the failure to differentiate the non-terrorist activities of revolutionary forces from terrorist ones results in commentators and scholars engaging in an ideological struggles to maintain the status quo rather than in the studying and understanding of terrorism in order to deal with this lethal problem.

When state terrorism is committed on indigenous peoples who do not have their own states, their victimization does not receive political attention. However, whenever such peoples organize themselves into liberation movements and engage in a struggle or whenever they start to use tactics similar to those of the state in order to defend their political and economic interests, they are labeled as "terrorists" and condemned by states. In a moral and legal sense, however, the colonized peoples have the right to self-defense without engaging in terrorism. According to the moral theorist Michael Waltzer (1977: 62), "Aggression justifies two kinds of violent response: a war of self-defense by the victim and a war of law enforcement by the victim and any other member of international society" [author's emphasis].

If we accept the position of mainstream commentators and scholars, then we should view the founding fathers of the U.S. as terrorists since they engaged in the American Revolution of 1776 to liberate their country from British domination. The failure to draw a clear boundary between a revolutionary activity and a terrorist practice has resulted in "irreconcilable antagonism" among researchers of terrorism and has complicated and frustrated the process of defining and theorizing terrorism (Cooper, 2001: 882). There is no wonder that the United Nations "could not reach any agreement on the definition of 'terrorism,' its root causes, or the appropriate steps necessary to be taken to cope with it" (Cline, 1970). In the modern world system in which "might is right" and in which states protect one another in the United Nations to avoid moral and political responsibilities (Jonassohn, 1998: 24) issues of terrorism are partially understood since the problem of state terrorism is ignored.

Members of the United Nations disagree on defining terrorism due to the emergence of three different approaches in understanding terrorism:

1). The position that terrorism is defined and constituted by the 'criminal acts' taken against governments by individuals or groups. Most of the advanced industrial Western states and some Latin governments support this position.

2). The position that terrorism should be defined by acts, but in a broader context than [the one] above so as to include acts of governmental groups those violate human rights and reinforce policies such as apartheid. This position was advanced primarily by the African states.

3). The position that the definition of terrorism resides in the motivation of the actor and the context of the act. This argument claims that to consider terrorism narrowly is to label inappropriately a freedom fighter as a terrorist. A variety of developing nations and Arab states held this view (Stohl and Lopez, 1984: 4).

Describing the disagreement of the members of the United Nations, Ambassador Charles Yost, the permanent United States representative to the United Nations in 1972, commented: "The fact is, of course, that there is a vast amount of hypocrisy on the subject of political terrorism. We all righteously condemn it - except when we or [our] friends are engaging in it. Then we ignore it or gloss over it or attach to it tags like 'liberation' or 'defense of the free world' or 'national honor' to make it seem like something [other] than what it is" (The Christian Science Monitor, 1972: 20). Such contradictory and dishonest interpretations complicate the problems of conceptualizing and understanding all forms of terrorism.

The problem of terrorism was given less attention until recently when Al Qaeda, a transnational terrorist organization masterminded by Osama bin Laden and his lieutenants, attacked the U.S. and other powerful countries such as Great Britain and Spain. Even currently, most scholars and non-academic experts focus on terrorist organizations such as Al Qaeda and fail to engage in a comprehensive study of terrorism. Political leaders, non-academic experts, media personalities, as well as most academics have ignored "the multiple meanings of terrorism" and focused on "the definition of behaviors, not with 
the real relations of domination and subjugation embodied in social structure" (Perdue, 1989: 10). As some terrorists have begun to demonstrate their global influence by mastering recent changes in technologies of communication and transportation as well as enhancing their organizational skills, the interest in studying terrorism has expanded (Hamm, 2007: 3). Because the revolution in technology "makes terrorism easier and deadlier," (Black, 2004: 22), the danger of terrorism is now widely felt in countries that used to be confident in their ability to maintain security. According to Yonah Alexander, Marjorie Ann Browne and Allan S. Nanes (1979: 9), "The brutality and globalization of modern violence make it amply clear that we have entered a unique 'Age of Terrorism' with all its formidable problems and frightening ramifications."

Until recently, only a few political scientists, sociologists, criminologists and non-academic experts were engaging in descriptive study of terrorism. Since September 11, 2001, more scholars and commentators have shown interest in terrorism studies, and more than one hundred books on terrorism have been published (Goodwin, 2006: 2027). But these descriptive studies have not dealt with the political economy of terrorism, and they have not recognized the importance of ideology in defining and labeling terrorism. According to William D. Perdue (1989: 4-5), "For the ideological construction of terrorism is a function of power; of the ability to control events and to impose one's ways upon others against their will. It follows from the preliminary and sensitizing argument to this point that power consists of more than overt force and coercion. Within its nature must be found an ability to define events and to broadly disseminate the official view." The dominant ideology of terrorism has attempted to dismiss all legitimate national or revolutionary movements that have attempted to overthrow oppressive and exploitative institutions and states by labeling them terrorist movements. In such cases, as Perdue comments: "Terrorism is a label of defamation, a means of excluding those so branded from human standing. When applied in a one-sided fashion to those who struggle against established political structures, it is a means of organizing both the perceptions and reactions of others in the world community. Once so defined, those affected may become international lepers. Hence their objectives, ideology, and historical reason for being will be dismissed out of hand. Paradoxically then, the very label of terrorism has of itself assumed a terrifying power" (Perdue, 1989: 4).

Although there have been legitimate reasons why colonized peoples have employed guerrilla methods to liberate themselves from colonial institutions, colonial states and their supporters have labeled them "savage" and "terrorist." "The concept 'ideology' reflects the one discovery which emerged from political conflict," Karl Mannheim (1936: 40) notes, "namely, that ruling groups can in their thinking become so intensively interest-bound to a situation that they are simply no longer able to see certain facts which would undermine their sense of domination." Since terrorist experts do not deal with the chains of causation of terrorism, "there is little theoretical knowledge available about the nature and sources of state organized terror" (Bushnell et al, 1991: 8) and about other forms of terrorism. Government officials, journalists, non-academic experts, and some scholars use the term terrorism without providing either a rigorous definition or adequate theorization of it. "The domi- nant ideology of terrorism," Perdue (1989: 8) notes, "refers to a specific thought-system held by institutional elite; the higher circles of political, economic, and military power committed to the preservation of an existing material and super-structural order".

This ideology is a roadblock to critically defining and theorizing terrorism. There are scholars who think that we can adequately study terrorism without a comprehensive definition of it. For example, Walter Laqueur (1977: 5) asserts, "a comprehensive definition of terrorism does not exist nor will it be found in the foreseeable future. To argue that terrorism cannot be studied without such a definition is manifestly absurd." Yet, without an acceptable objective definition of terrorism, our research into this subject and our effort to deal with it remains elusive. As Jack P. Gibbs (1989: 329) explains, "Leaving the definition [of terrorism] implicit is the road to obscurantism." This same scholar argues that since "labeling actions as "terrorism' promotes condemnation of the actors, [and since] a definition may reflect ideological or political bias," some scholars and others have avoided defining terrorism (Gibbs, 1989: 329). It can be argued that, in the name of political neutrality, most scholars shy away from comprehensively defining, theorizing, confronting, and challenging all forms of terrorism as a crime against humanity.

The life and liberty of all human groups should be recognized and defended on an equal level: morally, politically, and intellectually. Otherwise, to oppose one form of terrorism while supporting or promoting another is, I argue, a moral corruption and self-defeating. To expand our understanding of all forms of terrorism, we need to broaden our scope by studying the complex subject of terrorism in its global and historical context. Whether non-state actors, powerful states, or other entities commit lethal political violence against noncombatant populations, we must recognize the act as terrorism. However, we need to know that we cannot adequately understand non-state terrorism without understanding state terrorism. Paul Wilkinson (1981: 467) expounds that "we should not lose sight of the fundamental truth that one couldn't adequately understand terrorist movements without paying some attention to the effects of the use of force and violence by states. Indeed some of the best historical case-studies of the use of factional terrorism as a weapon vividly demonstrate how state violence often helps to provoke and fuel the violence of terrorist movements."

The state has the capacity to coordinate and concurrently use oppression, repression, exploitation, terrorism, and genocide (Stohl and Lopez, 1984: 7). "Although human rights advocates have awakened those [who] would listen to the human tragedy of violation of civil rights and liberties [by every government]," John F. McCamant (1984: 11) writes, "social scientists have, by and large, continued to ignore political repression" and state terrorism. In the globalized world order, state-sponsored terrorism still plays a central role in maintaining racial/ethnic hierarchies (Jalata, 2001). So without critically comprehending the causal relationship between bottom-up terrorism and top-down terrorism and without developing appropriate human rights-based policies, the so-called war on global terror cannot effectively address and solve this lethal problem. In the current global system, the notion of "might is right" is being challenged with the expansion of modern education, skills, knowledge, and technological information in different corners of the 
world. With the intensification of globalization and the expansion of knowledge and information, old ideologies that created and justified double standards among human groups based on race, culture, religion, and civilization cannot be maintained. The use of massive human rights violations including terrorism and genocide are increasingly becoming outdated, unpopular, unprofitable, and expensive both financially as well as in human lives, and cannot be sustained.

In an attempt to present a more comprehensive and broader definition of terrorism, I define terrorism as a systematic governmental or organizational policy through which lethal violence is practiced openly or covertly to impose terror on a given population group, their institutions or symbols, or their representative members in order to change their behavior of political resistance to domination or their behavior of domination for political and economic gains or other reasons. I am not suggesting that the impact of top-down and bottom-up terrorism are the same although all forms of terrorism destroy human lives, institutions, and properties. Instead, I am arguing that non-state terrorism is mainly caused by state terrorism directly or indirectly, and the later is more destructive than the former. According to John W. Sloan (1984: 84), "Since governmental groups have the resources of the state at their disposal, they are usually capable of engaging in higher levels of terrorism than the guerrillas." However, transnational terrorist organizations such as Al Qaeda also have adequate human, financial, and intellectual resources to impose horrifying terrorist activities on targeted audiences on a global level.

All forms of terrorists attempt to hide the lethal consequences of terrorism and their crimes against humanity by discoursing over civilization, progress, democracy, national liberation or religion. Some people are easily persuaded by such discourses and take sides without truly understanding the consequences. Furthermore, the terrorism that powerless or colonized peoples experience receives inadequate attention while terrorism that is visited upon powerful groups or nations receives much more attention and publicity. Some states and powerful people refuse to address that all human groups have the right to life and liberty and that they should be protected from all forms of terrorism.

In the name of "free markets," economic liberalization, the promotion of democracy, and a global war against terrorism, Western powers and some states in the Global South still engage in terrorism and hidden genocide to implement their economic and political policies. "The war on terrorism is being used as a continuation of the war on social justice," Hester Eisenstein (2001: 136) writes, "[it is a war] waged with the economic weapons of the international financial institutions." Western powers, multinational corporations, and state elites in developing countries have collaborated and engaged in massive human rights violations and terrorism (Richter, 1990) despite the fact that Western-based human right organizations have systematically exposed such crimes in different corners of the world. Bushnell, Shlapentokh, Vanderpool, and Sundram (1991:11) identify four conditions that are associated with the development of state terrorism: "They are: 1) distorted conceptions of the state and society and their inter-relationship, 2) the disarray of state institutions, 3) the presence of deep economic and/or ethnic conflicts in society or between the society and the state, and 4) state dependence on foreign power."
State terrorism begets non-state terrorism. In theorizing non-state terrorism, Roberta Senechal de la Roche (1996: 97-128) asserts that the accumulation of grievances causes terrorism and "social polarization" between socially and culturally distant groups. Long standing collective grievances and the right social geometry, such as a higher degree of cultural and religious differences, relational distance, and social inequality between the aggrieved and dominant population groups can sometimes contribute to the development of non-state terrorism (Crenshaw, 1981; Black, 2004). Jeff Goodwin (2006: 2038) advances a theory of categorical terrorism: "The main strategic objective - the primary incentive - of categorical terrorism is to induce complicitous civilians to support, or to proactively demand changes in, certain government policies or the government itself. Categorical terrorism, in other words, mainly aims to apply such intense pressure to complicitous civilians that they will demand that 'their' government change or abandon policies that the revolutionaries oppose." Using this theory, Goodwin concludes that Al Qaeda attacked the United States on September 11, 2001, because they considered American citizens to be "complicitous citizens" who support the foreign policy of the U.S. in the Middle East.

Similarly, Ward Churchill (2003) severely criticizes the American people for not preventing U.S. policies and actions that have caused massive human rights violations around the world; he also asserts that claiming "innocence" or ignorance of the facts cannot absolve them from being accountable for the government that they put in power through election. Faith Attaguile (2004: 3) also suggests that "until we take responsibility for terrorism perpetrated in our name, and until we end that terror, we can't stop the terror returned." However, I assert that although the American people have moral and political responsibility to make their government accountable, the failure to do this cannot justify terrorist attacks on them such as that of 9/11.

Churchill (2003: 10) explains why those who oppose unfair U.S. policies sometimes decide to engage in terrorism and have twisted minds: "whoever they might otherwise have been or become the sheer and unrelenting brutality of the circumstances compelling their response is all but guaranteed to have twisted and deformed their outlooks in some truly hideous ways." So by fighting against $\mathrm{Al}$ Qaeda and other related terrorist organizations without dealing with chains of factors that "twisted and deformed their outlooks in some truly hideous ways," we cannot comprehensively understand and solve the problem of global terrorism and other forms of terrorism. By focusing on the case of 9/11 and also that of Ethiopian state terrorism, I will further elaborate on the impact of terrorism from below and above.

\section{9/11 and Terrorism Studies}

The terrorist event of 9/11 shocked me as it did all Americans and the international community as a whole. The destruction of the American human lives was devastating and convinced Americans and others that no one is safe from the threat of terrorism in the modern world system. The U.S., the current superpower of the modern world, with its massive nuclear arsenal, complex intelligence networks, and highly advanced military capabilities, was attacked on its own soil by members of a terrorist organization willing to commit suicide in order to 
murder innocent civilians. Before this, I never imagined the possibility of this kind of terrorism. The use of commercial planes for a terrorist warfare was new and unexpected. Attesting to this new reality Noam Chomsky (2002: 11-12) states the following:

The horrifying atrocities of September 11 are something quite new in world affairs, not in their scale and character, but in the target. For the United States, this is the first time since the War of 1812 that the national territory has been under attack, or even threatened. Many commentators have brought up a Pearl Harbor analogy, but that is misleading. On December 7, 1941, military bases in two U.S. colonies were attacked - not the national territory, which was never threatened. The U.S. preferred to call Hawaii a 'territory,' but it was in effect a colony. During the past several hundred years the U.S. annihilated the indigenous population - intervened violently in the surrounding region, conquered Hawaii and the Philippines (killing hundreds of thousands of Filipinos), and, in the past half century particularly, extended its resort to force throughout much of the world. The number of victims is colossal. For the first time, the guns have been directed the other way. That is a dramatic change.

This new "dramatic change" in world affairs forces us to go beyond an ideologically and culturally blind lens to understand the causes and effects of all forms of terrorism in the modern world system.

On September 11, 2001, nineteen terrorists belonging to the Al Qaeda network hijacked four U.S. commercial jet planes and crashed two planes into the twin towers of New York's World Trade Center and one into the headquarters of the Department of Defense, the Pentagon, in Washington D.C. American Flight 11 was crashed into Tower One of the World Trade Center at 8:45 a. m., tearing a gaping hole into the building and setting it afire. United Airlines Flight 175 was crashed into Tower Two at 9:03 a. m. Both buildings started to burn furiously, sending a massive cloud of dust and debris into the air. Consequently, Tower Two collapsed to the ground at about 10:05 a.m. and Tower One at 10:28 a. m. At 9:43 a. m., a third plane, American Airlines Flight 77 slammed into the Pentagon, the U.S. military headquarters, killing 184 people and destroying a section of the building. After a huge plume of smoke went up, a portion of the Pentagon collapsed at 10:10 a. m. A fourth jet crashed in Somerset County, Pennsylvania, at 10:10 a. m. without reaching its target, which was probably the White House or the Pentagon or the Capitol. As a result of this crash in Pennsylvania, 40 people perished. The terrorists who hijacked these four commercial planes attacked American military and economic symbols to undermine American confidence in the modern world system.

These terrorists successfully transformed these commercial jets into war machines that terrorized the citizens of the United States and committed horrific crimes against humanity. The effects of these terrorist attacks were devastating and shocking: 3,000 people were murdered "in these attacks, the vast majority of them in the collapse of the New York skyscrapers, whose metal structure melted in the fires caused by the explosion of the two airliners" (Blin 2007: 413). Furthermore, 343 firefighters lost their lives and 1,337 vehicles were crashed when the towers collapsed. According to Arnaud Blin (2007: 413), "The 9/11 attacks were the highest achievement yet by a terrorist group: in media terms (the attacks were broadcast alive around the world); symbolically (the attacks struck at the core of America's center and military establishment); and statistically, with the large numbers of victims (the term 'mega terrorism' was used). There was no doubt that, psychologically, America and much of the world, especially in the West, was in a state of shock."

Like other forms of terrorism, this terrorism did not spare children, women, and elders. Thousands of children also lost their parents. The surviving families and the relatives of terrorist victims were denied any closure and comfort that they could have received from a proper burial "because many of the victims of the twin towers disaster were burned beyond recognition and beyond identification by DNA matching" (Gareau, 2004: 11). Although it is very difficult to know exactly the financial damage inflicted upon the United States by the event of $9 / 11$, one source estimates it to be about $\$ 285$ billion. According to the Office of Management and Budget, without including Homeland Security, the wars in Iraq and Afghanistan and other global wars on terroristic operations since 9/11 cost $\$ 110$ billion by FY 2007. In the past, it was usually the West and their client states in the Rest that engaged in state terrorism. But in the case of 9/11, a terrorist group from the Rest, the Middle East particularly attacked the United States. The terrorist events of $9 / 11$ changed the modern world dramatically; consequently we have entered into an age of terror. Due to new technologies and new organizational capacities the West "lost their virtual monopoly of violence" and "[f]or the first time in modern history was subjected, on home soil, to the kind of atrocity that they routinely have carried out elsewhere" (Chomsky, 2002: 119). This terrorist tragedy would help us in correctly and profoundly reflecting on the proximate and immediate causes of all forms of terrorism in order to find a lasting solution for this crime against humanity.

The 9/11 terrorist episodes renewed in my mind the nightmares, pain, and frustration that forced me to leave my homeland, Oromia. It made me feel that terrorism was following me to the United States, a place that I thought was immune to terrorism. The terrorism events of 9/11 traumatized the citizens of the United States as well as me just like successive Ethiopian regimes have been terrorizing the Oromo and other peoples. The only difference is that the former was committed by a transnational terrorist organization and the latter by a state with support from global powers, particularly the United States. To illustrate the impact of state terrorism, let us explore the effects of Ethiopian state terrorism on the Oromo people.

\section{The Impact of Ethiopian State Terrorism on the Oromos}

The Ethiopian colonial terrorism that started during the last decades of the $19^{\text {th }}$ century still continues into the $21^{\text {st }}$ century. Ethiopia, formerly known as former Abyssinia, terrorized and committed genocide on the Oromo and other peoples during the Scramble for Africa with the help of European imperial powers and the modern weapons they received from them (Holcomb and Ibssa, 1990; Jalata, 1993). During Ethiopian colonial expansion, Oromia, "the charming Oromo land, [would] be 
ploughed by the iron and the fire; flooded with blood and the orgy of pillage" (De Salviac, 2005[1901]: 349). Calling this event as "the theatre of a great massacre," Martial De Salviac (2005: 349) states,

The conduct of Abyssinian armies invading a land is simply barbaric. They contrive a sudden irruption, more often at night. At daybreak, the fire begins; surprised men in the huts or in the fields are three quarter massacred and horribly mutilated; the women and the children and many men are reduced to captivity; the soldiers lead the frightened herds toward the camp, take away the grain and the flour which they load on the shoulders of their prisoners spurred on by blows of the whip, destroy the harvest, then, glutted with booty and intoxicated with blood, go to walk a bit further from the devastation. That is what they call 'civilizing a land.'

Oral stories passed down by the Oromo oral story also testifies that Ethiopians/Abyssinians (Amharas and Tigrayans) and their supporters destroyed and looted the resources of Oromia, committed genocide against the Oromo people during and after they colonized Oromia through massacring, enslavement, depopulation, cutting of hands, man-mad famines, and diseases. It was particularly European firearms that enabled the Abyssinians to defeat their formidable contenders, the Oromos. According to Martial De Salviac (2005: 8), "With equal arms, the Abyssinia [would] never [conquer] an inch of land. With the power of firearms imported from Europe, Menelik [Abyssinian warlord] began a murderous revenge." The violent colonization of Oromia, the Oromo country, involved human tragedy and the merchandizing of the Oromo: "The Abyssinian, in bloody raids, operated by surprise, mowed down without pity, in the country of the Oromo population, a mournful harvest of slaves for which the Muslims were thirsty and whom they bought at very high price. An Oromo child [boy] would cost up to 800 francs in Cairo; an Oromo girl would well be worth two thousand francs in Constantinople" (De Salviac, 2005: 8).

The Ethiopian colonial government massacred half of the entire Oromo population (five million out of ten million) and their leadership during its colonial expansion into Oromia (De Salviac, 2005: 6-8, 278; Bulatovich, 2000: 68-69). According to Alexander Bulatovich (2000: 68-69), "The dreadful annihilation of more than half of the population during the conquest took away from the Gallas [Oromos] all possibilities of thinking about any sort of uprising." The destruction of Oromo lives, institutions, and liberty were aspects of Ethiopian colonial terrorism.

Most Oromos who used to enjoy an egalitarian democratic system known as the gadaa system (Legessee, 2000) were forced after colonization to face political repression and an impoverished life. Before their colonization, the Oromo had the gadaa system that had the principles of checks and balances, balanced opposition, and power sharing between higher and lower administrative organs to prevent the falling power into the hands of despots. Other aspects included a balanced representation of clans, lineages, regions, and confederacies; accountability of leaders; the settlement of disputes through reconciliation; and respect for basic rights and liberties.

Alexander Bulatovich (2000: 68) explains about the gadaa administration, and notes that:" The peaceful free way of life, which could have become the ideal for philosophers and writers of the eighteenth century, if they had known it, was completely changed. Their peaceful way of life is broken; freedom is lost; and the independent, freedom loving Gallas [Oromos] find themselves under the severe authority of the Abyssinian conquerors."

Ethiopian colonialists also destroyed Oromo natural resources and the beauty of Oromia. Oromia was once "an oasis luxuriant with large trees" and known for its "opulent and dark greenery used to shoot up from the soil" (De Salviac, 2005: 21-22). Bulatovich (2000: 21) who visited Oromia between 1892 and 1896 applied to this country the phrase "flowing in milk and honey" to indicate its abundant wealth in cattle and honey. De Salviac (2005: 21) also notes that "the greenery and the shade delight the eyes all over and give the landscape richness and a variety which make it like a garden without boundary. Healthful climate, uniform and temperate, fertility of the soil, beauty of the inhabitants, the security in which their houses seem to be situated, makes one dream of remaining in such a beautiful country." Yet, the Abyssinian colonialists devastated "the forests by pulling from it the laths for their houses and [made] camp fires or firewood for their dwellings... [They were] the great destructors of trees, others [accused] them of exercising their barbarity against the forests for the sole pleasure of ravaging" (De Salviac, 2005: 20).

The Ethiopian colonial state established settler colonialism in Oromia and developed five major types of colonial institutions, namely, slavery, the colonial landholding system, the nafxanya-gabbar system (semi-slavery), the collaborative class, and garrison and non-garrison cities. It introduced the process of forced recruitment of labor via slavery and the nafxanya-gab- bar (semi-slavery) system (Holcomb and Ibssa, 1990: 135). The colonial state expropriated almost all Oromo lands and divided up and distributed the land and its inhabitants among colonial officials, soldiers and their collaborators in order to extract by force agricultural commodities and food for both local consumption and the international market. The remaining Oromos were reduced to serfs, slaves or semi-slaves and coerced to work without remuneration for the settlers, intermediaries, and the colonial state for certain days every week. Whenever they failed to provide free labor or pay taxes or tributes, the settlers enslaved their children and wives.

The repression, exploitation, and terrorism started under the reign of Menelik continued under successive Ethiopian governments. The Haile Selassie government continued the policies of Menelik until it was overthrown by the popular revolt of 1974. The Haile Selassie government terrorized the Oromo of Raya-Azabo, Wallo, Hararghe, Bale and other regions because of their political and cultural resistance to the Amhara-Tigray domination. It also imprisoned, tortured, and hanged prominent Oromo leaders such as Mamo Mazamir and Haile Mariam Gamada and banded Oromo civic organizations and musical groups in the 1960s.

The military regime that emerged in 1974 under the leadership of Colonel Mengistu Haile Mariam to replace the Haile Selassie government also continued dictatorial rule, colonial policies and colonial terrorism. When Oromo activists and the people started to resist the military regime, the regime intensified its state terrorism. The military regime (derg) and its supporters committed massive human rights violations in the name of the "Ethiopian Revolution." According to Norman J. Singer 


\section{(1978: 672-673),}

"Those killed in the first three months of [the] campaign [of] the 'Red Revolutionary Terror' numbered around 4000-5000 [in Finfinnee alone], the killings continued in March 1978, spreading to the rest of the country Those detained for political instruction numbered from 30,000 upwards Torture methods emphasized in the Red Terror included severe beating on the head, soles of the feet and shoulders, with the victim hung by the wrists or suspended by wrists and feet from a horizontal bar; sexual torture of boys and girls, including pushing bottles or red-hot iron bars into girls' vaginas; and other cruel methods."

The derg continued its terrorism, mass imprisonments, and killings throughout its rule. In 1980, one Oromo source mentioned that "the Oromo constitutes the majority of the more than two million prisoners that glut Ethiopia's jails today" (The Oromo Relief Association, 1980: 30). In the 1980s, thousands of Oromo nationalists were murdered or imprisoned; the regime also terrorized other elements of Oromo society. According to Gunnar Hasselblatt (1992: 17-19),

The military government repeatedly held mass shootings among the Oromo population, hoping to break the free, independent Oromo spirit. Sometimes a hundred, sometimes two hundred men were shot on this raised dry field and were buried with bulldozers. Over years this procedure was repeated several times. When the method did not work and the Oromo population could not be forced into submission, other methods were used. The victims were made to lie down with their heads on stone, and their skulls were smashed with another stone. The government tried everything to consolidate its reign of terror and exploitation of Oromia When the Oromo movement could not be quenched by shooting or by the smashing of skulls, [the government] came up with a new idea. Men's testicles were smashed between a hammer and an anvil. Three men tortured and maimed in this way are still living.

As Ethiopia terrorized and colonized the Oromo nation with the help of European powers such as Great Britain, France, and Italy, it has maintained its oppressive and repressive structures by receiving assistance from successive global powers, namely Great Britain, the former Soviet Union, and United States (Jalata, 2001). Today, Ethiopian colonial settlers led by the Tigrayan-led regime have dominated cities in Oromia and segregated the Oromo national majority in urban and rural areas and kept them under "Ethiopian political slavery" by using the army, modern weaponry, the media, communication and information apparatus and networks. Using political violence, the Tigrayan authoritarian-terrorist regime has totally controlled the Oromo and denied them the freedom of expression, association, organization, and the media, and all forms of communication and information networks.

Since the Tigrayan-dominated Ethiopian government is weak, illegitimate, and lacks accountability and professionalism, it engages in terrorism and hidden genocide to protect its power. This regime is committed to improving the living standards of the Tigrayan population group at the cost of colonized population groups, particularly the Oromos. Since most of the Oromo people, under the leadership of the Oromo Liberation Front
(OLF), are determined to challenge the racist and terrorist policy of this regime, this government mainly targets to destruct and devastate the Oromos (Jalata, 2005: 243-247). Ethiopian state terrorism manifests itself in different forms. Its obvious manifestation is violence in the form of unjustified war, assassination, murder, castration, burying alive, throwing off cliffs, hanging, torture, rape, forcing people to submission by intimidation, beating, and disarmament (Pollock; 1996, 1997; Trueman, 1997).

Former prisoners have testified that their arms and legs were tied tightly together on their backs and their naked bodies were whipped. Large containers or bottles filled with water were fixed to their testicles, or if they were women, bottles or poles were pushed into their vaginas. There were prisoners who were locked up in empty steel barrels and tormented with heat in the tropical sun during the day and with cold at night. There were also prisoners who were forced into pits so that fire could be made on top of them. Currently, tens of thousands of Oromos are imprisoned, tortured, harassed or killed by the Meles regime because of their continuing struggle for national self-determination and democracy. Although it is not possible to exactly know at this time how many Oromos have been murdered because the Meles government keeps this type of information hidden, the Oromia Support Group in 1996 reported that there were "3,981 extra-judicial killings and 943 disappearances [euphemism for hidden murder] of civilians suspected of supporting groups opposing the government" (The Oromia Support Group, 2007: 1). Since 1992, security forces have imprisoned thousands of Oromos on charges of plotting armed insurrections on behalf of the Oromo Liberation Front (OLF). Such accusations have regularly been used as a transparent pretext to imprison individuals who publicly question government policies or actions. Security forces have tortured many detainees and subjected them to continuing harassment and abuse for years after their release. Such harassment has in turn often destroyed victims' ability to earn a livelihood and has isolated them from their communities.

People like the Oromos who do not have personal safety in their own homes or public safety in their communities and also who are denied the freedom of expression, association, and organization, do not have a good quality of life. In this $21 \mathrm{st}$ century, with quickly changing world due to the intensification of globalization, social revolutions, and revolutions in technology, information, communication, and transportation, the Oromo people are in the darkness of ignorance and poverty. When a community or a society lacks independence or autonomy to determine its own political destiny, it is confronted with the problems of underdevelopment, which is characterized by powerlessness, victimization, illiteracy, poverty, and other forms of socioeconomic crises. Ethiopian state repression and violence including terrorism have resulted in deep social, political, cultural and economic crises in Oromo society.

\section{Reflecting on Ethiopian and Al Qaeda Terrorism}

The dramatic terrorist event on September 11, 2001, in the U.S. reminded me about the destruction of human lives and liberty within the Ethiopia under the terrorist regimes of Mengistu Haile Mariam and Meles Zenawi, responsible for the 
massacring of millions of Oromos and others because of their political beliefs and ethnonational backgrounds. The current Tigrayan-led Ethiopian government practices state terrorism against the Oromo, Sidama, Annuak, and Somali peoples as a means of establishing political stability and order.

Despite the fact that Ethiopian terrorism has been committed by successive Ethiopian governments and the 9/11 terror attack was committed by a transnational organization, I argue that the effects of these forms terrorism are very similar. Like the innocent Americans who were burned alive and denied a proper burial during the terrorist episodes of 9/11, most Oromos who have been murdered by agents of the Ethiopian government are eaten by hyenas and denied a proper burial as well. The relatives of murdered Oromos are not allowed to cry to express their sadness according to their cultural tradition. Except from human rights organizations such Amnesty International and Africa Watch, no attention has been given to the terrorism committed against the Oromo people. Unfortunately, the stories of millions of Oromos who have been massacred by successive Ethiopian regimes are little known by the international community.

While the U.S. and its allies are fighting against Al Qaeda and also engaging in an offensive war in Iraq, Afghanistan, and other countries, the Oromo people are mainly engaged in peaceful resistance without any support from the international community. Since I have no capacity to change this situation of the lack of international support for the Oromo, it pains and frustrates me. Furthermore, what is disturbing to me is that the U.S. government, my government, financially, militarily, and diplomatically supports the Ethiopian terrorist regime. My government assists the Meles regime, a regime that terrorizes my people, the Oromo, just as it supported the Haile Selassie regime from the 1950s to the 1970s (Jalata, 2005). When the Ethiopian military regime was overthrown in 1991, the U.S. came back to Ethiopia and continued its previous policy of supporting the Ethiopia state. What frustrates me more are the claims the U.S. government makes while supporting the Ethiopian government. It claims that it is committed to promoting democracy, human rights, and development in Ethiopia; it also claims that the Meles regime is one of its allies in fighting against global terrorism. Most Americans may believe these claims, but the reality on the ground in Ethiopia falsifies them (Jalata, 2005: 148-153).

Despite the fact that the U.S. government supports the regime of Ethiopia, a regime that engages in terrorism, it recognizes that the human rights of the Oromo and other peoples in Ethiopia are being violated. The U. S. State Department has annually published Country Reports on Human Rights practices of every country in the world since 1977 to claim that it cares for human rights. However, the U.S. government only gives lip service to the issues of human rights violations by terrorist states because "congress . . . has decreed that the executive cut off aid to any country that by its actions reveals a consistent pattern of violating human rights. No matter the restrictions, administrations determined to provide aid to governments practicing terrorism or in other ways violating human rights have usually succeeded. Moreover, the restrictions and the reporting give the impression that Washington is a firm upholder of human rights and a foe of terrorism" (Gareau, 2004: 16). In his impressive study, Frederick H. Gareau (2004: 16) demonstrates how the U. S. government supported state terrorism in Chile, El
Salvador, Argentina, Guatemala, Indonesia, Iraq, Cambodia (the Khmer Rouge), and South Africa, and has therefore contributed to the terrorist victimization of political and human rights activists, peasants, workers, union leaders, teachers, and priests and nuns. He concludes "that Washington was, and continues to be, an accomplice to state terrorism" (Gareau, 2004: 16).

The U.S. government has supported dictatorial and terrorist regimes such as Pinochet's government of of Chile. Despite the fact that the terrorist events of $9 / 11$ have forced the U.S. government to reevaluate its position on all forms terrorism, it is still "an accomplice to" the terrorism of states like that of Ethiopia. Washington's attempt to reevaluate its position is reflected in National Security Strategy of the United States of America (2002: 2): "to make clear that all acts of terrorism are illegitimate so that terrorism will be viewed in the same light as slavery, piracy, or genocide: behavior that no respectable government can condone or support and all must oppose". In actuality, if the U.S. government wants to directly confront the underlying causes of terrorism and oppose all forms of terrorism, it must recognize that state terrorism is a crime against humanity just as terrorism by non-state actors like Al Qaeda is and that it needs to stop supporting terrorist governments such as that of Ethiopia. What is a key to recognizing is that it is impossible to eliminate one form of terrorism while engaging in and/or supporting another.

\section{Discussion and Conclusions}

This paper has discussed current positions in studies of terrorism in an attempt to highlight the gaps in our knowledge of terrorism and to push forward an argument that can improve our understanding of what terrorism is in order to eliminate it. I have employed multidimensional, comparative methods, case studies, and critical approaches to examine the dynamic interplay among social structures, human agency, and terrorism and to grasp the issues of terrorism and globalization. I have asserted that without employing such approaches in studying terrorism, we will only continue to hold current dominant intellectual, political, philosophical, and ideological paradigms of domination and subordination that only perpetuate terrorist conflicts leading to a breakdown of the current global order.

While some states engage in terrorist activities in order to promote their economic and political agendas, non-state terrorist agencies use similar techniques to oppose and challenge such policies, behavior, and practices. Therefore, without making governments that engage in state terrorism directly or indirectly accountable for their policies and practices and without understanding and dealing with the root problems of terrorism, we cannot deal with a branch of terrorism: terrorism from below. As a crime against humanity, terrorism is a dark side of human civilization. Hence, it is urgent that scholars establish a single moral, intellectual, legal, and political position in the study and understanding of all forms of terrorism and suggest pragmatic policies to reduce and eventually eliminate the problem of terrorism in all its manifestations.

One of the central problems that all people who believe in social justice, human rights, peace, and democracy must confront is the lack of a single moral, legal, philosophical, intellectual standard to study, understand, and deal with all forms of 
terrorism. I have argued that whether terrorism is promoted by states or subversive organizations, it must be rejected both on policy and practical levels. The mechanisms of stopping terrorism and genocide require human-centric visions that go beyond self- and group-centered interests and ideologies that accept and practically implement the Universal Declarations of $\mathrm{Hu}-$ man Rights that expand democracy, and that establish an egalitarian and democratic world order.

\section{References}

Adelman, J. R. (1991). The Development of the Secret Police in Communist States. In P. Timothy Bushnell, V. Shlapentokh, C. K. Vanderpool and J. Sundram Eds.). State Organized Terror (pp. 99-112). Boulder: Westview Press.

Attaguile, Faith. (2004). Book Review: On the Justice of Roosting Chickens. Ward Churchill,

http://www.kersplebedeb.com/mystuff/books/reviews/churchill_lip.h tml.

Alexander, Browne, Y. M. and Nanes, A. S. (Eds.). (1979). Control of terrorism: International documents (pp. 9-10). New York: Crane, Russak \& Company.

Black, Donald. (2004). The Geometry of terrorism. Sociological Theory, 22, March, 21-22.

Bodley, J. H. (1990). Victims of Progress (3rd Ed.). Mountain View, Calif.: Mayfield Publishing Co.

Bodley, J. H. (1992). Anthropology and the politics of genocide. In Carolyn Nordstrom and JoAnn Martin (Eds.), The paths to domination, resistance, and terror (pp. 37-51). Berkeley: University of California Press.

Brian, J. (1981). A Strategy for Combating Terrorism. Santa Monica, California: Rand Paper Series.

Bulatovich, A. (2000). Ethiopia through Russian Eyes: Country in Transition. Translated by Richard Seltzer. Lawrenceville, NJ: The Red Sea Press.

Bushnell, T. et al. (1991). State organized terror: Tragedy of the modern state. In Timothy Bushnell, Vladimir Shlapentokh, Christopher K. Vanderpool, and Jeyaratnam Sundram (Eds.). State Organized Terror: The Case of Violent Internal Repression. Boulder: Westview Press

Chaliand, Gerard and Blin, Arnaud. (2007). The History of Terrorism from Antiquity to Al Qaeda. Translated by Edward Schneider, Kathryn Pulver, et. al. Los Angeles: University of California.

Cohen, J. M. (Ed.) and (Trans.) (1969). Christopher Columbus: The Four Voyages. London: Penguin Books.

Cooper, H. H. A. (2001). Terrorism: The problem of definition revisited. American Behavioral Scientist, 44, 2001, 881-893. doi:10.1177/00027640121956575

Chomsky, Noam. (2002). 9-11. New York: Seven Stories Press.

Cline, R. S. (1979). "Foreword." In byYonah Alexander, M. A. Brown and A. S. Nanes (Eds.). Control of Terrorism: International Documents. New York: Crane, Russak \& Company, Inc.

Crenshaw, Martha. (1981). The Causes of Terrorism. Comparative Politics, 13, 379-399. doi:10.2307/421717

Churchill, Ward. 2003. On the Justice of Roosting Chickens: Reflections on the Consequences of US Imperial Arrogance and Criminality. Oakland, CA: AK Press, 2003.

Davis, Mike. (2001). Late Victorian Holocausts: El Nino Famines and the Making of the Third World. London: Verso.

De Las Casas, Bartolome (1992). A Short Account of the Destruction of the Indies. Edited and Trans. by Nigel Griffin. London: Penguin Books.

De la Roche, Roberta, S. (1996). Collective violence as social control. Sociological Forum, 11, 97-128. doi:10.1007/BF02408303

De Salviac, Matial (2005) [1901]. An Ancient People, Great African Nation. Translated by Ayalew Kano. East Lansing, Michigan.

Enders, W and Sandler, T. (2006). The Political Economy of Terrorism.
New York: Cambridge University Press.

Eisenstein, H. (2001). After 9/11: Globalization and the Events of September 11, 2001. Socialism and Democracy: the bulletin of the Research Group on Socialism and Democracy, 24, 54.

Eqbal, A. (1998). Terrorism: Theirs and ours. A Presentation at the University of Colorado, 12 October. URL (last checked 8 June 2009) http://www.hartford-hwp.com/archives/27d/077.html, pp. 1-9.

Farsoun, S. K. and Aruri, N. H. (2006). Palestine and the Palestinians: A social and Political History. Boulder, Colorado: Westivew.

Frank, A. G. (1978). World Accumulation, pp. 1492-1789. New York: Monthly Review Press.

Frank, A. G. (1979). Dependent Accumulation and Underdevelopment. New York: Monthly Review Press.

Gareau, F. H. (2004). State Terrorism and the United States: From Counterinsurgency to the War on Terrorism. London: Zed Books.

Goodwin, Jeff. (2006). A theory of categorical terrorism. Social Forces, 84, 2027-2046. doi:10.1353/sof.2006.0090

Gibbs, J. P. (1989). Conceptualization of Terrorism. American Sociological Review, 54, 329-340. doi:10.2307/2095609

Glubb, Sir J. B. (1957). A Soldier with the Arabs. New York: Harper and Row.

Hasselblatt Gunnar, Gunnar. (1992). After fourteen years: Return to Addis Ababa — and to a free Oromia. December 1991 - January. A Travel Diary, Berlin, pp. 17-19.

Hamm, M. S. (2007). Terrorism as Crime. New York: New York University Press.

Herman, E. S. (1982). The Real Terror Network: Terrorism in Fact and Propaganda. Boston: South End Press.

Held, V. (2004). Terrorism, Rights, and Political Goals. In Igor Primoratz (Ed.). Terrorism: The Philosophical Issues (pp. 65-79). New York: Palgrave.

Hoffman, Bruce. 2006[1998]. Inside Terrorism, (New York: Columbia University.

Holcomb, H. and Ibssa, S. (1990). The Invention of Ethiopia. Trenton: The Red Sea Press.

Hochschild, Adam. (1999). King Leopold's Ghost: A Story of Greed, Terror, and Heroism in Colonial Africa. New York: Houghton Mifflin Company.

Jalata, Asafa. (2001). Fighting Against the Injustice of the State and Globalization: Comparing the African American and Oromo Movements. New York: Palgrave.

Jalata, A. (2005[(1993]). Oromia \& Ethiopia. Trenton, NJ: The Red Sea Press.

Johnassohn, Kurt. (1998). Genocide and Gross Human Rights Violations: In Comparative Perspective. New Brunswick: Transaction Publishers.

Kiernan, Ben. (2007). Blood and Soil. New Haven: Yale University Press.

Lenin, V. I. (1971). State and Revolution. New York: International Publications.

Manneheim, Karl. (1936). Ideology and Utopia. New York: A Harvest/HBJ Book

Maguire, John. (1978). Marx's Theory of Politics, (Cambridge: Cambridge University Press.

Marx, Karl. (1967). Capital. F. Engels (Ed.). New York: International Publishers.

McCamant, J. F. (1984). Governance without blood: Social science's antiseptic view of rule; or, the neglect of political repression." In Michael Stohl and George A. Lopez (Eds.). The State as Terrorist (pp. 11-42). Westport, Connecticut: Greenwood Press.

National Security Strategy of the United States of America, 2002.

Nassar, J. R. (2005). Globalization and Terrorism: The Migration of Dreams and Nightmares. New York: Rowman \& Littlefield Publishers.

Netanyahu, B. (1995). Fighting Terrorism. New York: Farrar Straus Giroux.

Laqueur, Walter. (1977). Terrorism. London: Weidenfeld and Nicolson.

Legessee, A. (2000). Oromo Democracy. Lawrenceville: Red Sea 
Press.

Lizardo, Omar. (2008). Defining and theorizing terrorism: A global actor-centered approach. Journal of World-Systems Research, 14, 91-118.

Oliverio, A. (1998). State of Terror. Albany: State University of New York Press.

O'balance, E. (1957). The Arab-Israeli War, 1948. New York: Praeger.

Oots, Kent L. (1986). A Political Organization Approach to Transnational Terrorism. New York: Greenwood Press.

Perdue, W. D. (1989). Terrorism and the State. New York: Praeger.

Pollock, Sue. (1996). Ethiopia - Human Tragedy in the Making: Democracy or Dictatorship? The Oromia Support Group.

Pollock, Sue (1997). Politics and conflict: Participation and self-determination In Ethiopia. Conquest and the Quest for Freedom and Democracy (pp. 81-110). London: TSC Publications.

Polanyi, Karl. (1944). The Great Transformation. New York: Farrar and Rinehart.

Richter, Robert. (1990). Hungry for Profit. New Day Film library, 22 D Hollywood Ave., Ho-Ho-Kus, NJ 07423.

Shaw, Martin. (2003). War \& Genocide. Cambridge, UK: Polity.

Schmid, A. P. and Jongman, A. J. (1988). Political Terrorism: A New Guide to Actors, Authors, Concepts, Data Bases, Theories and Literature. Amsterdam: Swidoc.

Schmid, A. P. (1991). Repression, state terrorism and genocide: Conceptual clarifications. In P. Timothy Bushnell, V. Shlapentokh, et al. (Eds.). State Organized Terror (pp. 23-37). Boulder: Westview Press).

Singer, Norman J. (1978). Ethiopia: Human Rights, 1948-1978. Proceeding of the First International Conference on Ethiopian Studies. April 13-16.

Sloan, J. W. (1984). State repression and enforcement terrorism in Latin America. In Michael Stohl and George A. Lopez The State as Terrorist (pp. 83-89). Westport: Connecticut, Greenwood Press.

Stohl, M and George, A. Lopez, G. A. (1984). Introduction. In Michael Stohl and George A. Lopez (Eds.). The State as Terrorist: The Dynamics of Governmental Violence and Repression (pp. 3-10). Westport, Connecticut: Greenwood Press.

Tilly, Charles. (1985). War making and state making as organized. In Peter Evans, Dietrich Ruesschemeyer, and Theda Skocpol, (Eds.),
Bringing the State Back In (pp. 169-187). Cambridge: Cambridge University Press.

The Christian Science Monitor, 14 September 1972: 20.

The Oromo Relief Association. (1980).

The Oromia Support Group. (2007).

(Tony) Coady, C. A. J. (2004). Terrorism, morality, and supreme emergency. In Igor Primoratz (Ed.). Terrorism: The Philosophical Issues (pp. 80-96). New York: Palgrave.

Trueman, Trevor. (1995). Democracy or dictatorship. In Seyoum Y. Hameso, T. Trueman, and T. E. Erena. (Eds.). Conquest and the Quest for Freedom and Democracy (pp. 141-150). London: TSC Publications.

Thornton, Russell. (1987). American Indian Holocaust and Survival: A Population History Since 1492. Norman and London: University of Oklahoma Press.

Waltzer, Michael. (1977). Just and Unjust Wars: A Moral Argument with Historical Illustrations. New York: Basic Books.

Wardlaw, Grant. (1989). Political Terrorism: Theory, tactics, and counter-erasures $\left(2^{\text {nd }}\right.$ Edition). Cambridge: Cambridge University Press.

Wallerstein, I. (1974). The Modern World-System. New York: Academic Press.

Wallerstein, I. (1980). The Modern World-System II: Mercantilism and the Consolidation of the European World-Economy, 1600-1750. New York: Academic Press.

Weinberg, L., Pedahzur, A. and Hirsch-Hoefler, S. (2004). The challenges of conceptualizing terrorism. Terrorism and Political Violence, 16, 777-794. doi:10.1080/095465590899768

Welsh, Bridget. (2002). Globalization, weak states, and death toll in East Asia. In Kenton Worcester, Sally Avery Bermanzohn, and Mark Ungar. Violence and Politics; Globalization's Paradox. New York: Routledge.

Wilkinson, Paul. (1986). Terrorism and the Liberal State (2 ${ }^{\text {nd }}$ Edition.) London: Macmillan.

Wilkinson, P. (1981). Can a state be 'Terrorist'?' International Affairs 57, summer, 467-472.

Wilkinson, Paul. (1979). Social scientific theory and civil violence. In Yonah Alexander, David Carlton, and Paul Wilkinson, (Eds.). Terrorism: Theory and Practice (pp. 45-72). Boulder: Westview Press. 